\title{
ANASLISIS KINERJA KEUANGAN DAN KEMANDIRIAN DAERAH KABUPATEN MOROWALI
}

\author{
Sitti Khalilah Yusuf \\ Muslimin \\ Husnah \\ Manajemen, Ekonomi, Universitas Tadulako \\ E-mail: khalilahyusuf96@gmail.com
}

\begin{abstract}
Analysis of Financial Performance and Regional Independence of Morowali District. In the implementation of regional autonomy, the district government is required to be able to finance its own governance. This indicates that local governments have greater responsibilities in managing their finances and increasing their level of regional autonomy. In this regard, it is necessary to conduct performance appraisal and financial capacity of local government to know the development of financial management every year. This research uses descriptive quantitative research type using ratio analysis tool. The results of the analysis show that the Financial Performance of Morowali District Government is seen from (1) Effectiveness Ratio of PAD effectiveness of financial performance of Morowali Regency can be categorized as Not Effective (2) Ratio of Financial Efficiency of Region can categorize Less Efficient (3) Economic Ratio can be categorized economically (4) Regional Financial Independence can be said to be very low with an instructive relationship pattern.
\end{abstract}

Keywords: financial performance and independence of morowali district

\begin{abstract}
ABSTRAK
Analisis Kinerja Keuangan dan Kemandirian Daerah Kabupaten Morowali. Dalam pelaksanaan otonomi daerah, pemerintah Kabupaten dituntut untuk mampu membiayai sendiri penyelenggaraan pemerintahan. Hal ini menandakan pemerintah daerah memiliki tanggung jawab lebih besar dalam mengelola keuangan serta meningkatkan tingkat kemandirian daerahnya. Sehubungan hal itu perlu dilakukan penilaian kinerja serta kemampuan keuangan pemerintah daerah untuk mengetahui perkembangan pengelolaan keuangan setiap tahun. Penelitian ini menggunakan jenis penelitian deskriptif kuantitatif dengan menggunakan alat analisis rasio. Hasil analisis menunjukkan bahwa Kinerja Keuangan Pemerintah Daerah Kabupaten Morowali dilihat dari (1) Rasio Efektivitas PAD efektivitas kinerja keuangan Kabupaten Morowali dapat dikategorikan Tidak Efektif (2) Rasio Efisiensi Keuangan Daerah dapat kategorikan Kurang Efisien (3) Rasio Ekonomis dapat dikategorikan ekonomis (4) Rasio Kemandirian Keuangan Daerah dapat dikatakan tergolong sangat rendah dengan pola hubungan instruktif.
\end{abstract}

Kata Kunci: Kinerja Keuangan dan Kemandirian Kabupaten Morowali.

\section{PENDAHULUAN}

Kabupaten Morowali merupakan kabupaten hasil pemekaran wilayah Kabupaten Poso Propinsi Sulawesi Tengah. Kabupaten ini memiliki sumber daya alam yang besar terutama di sektor pertambangan. Sebagai kabupaten yang memiliki sumber daya alam yang besar tentunya memiliki dana yang cukup untuk menyelenggarakan kegiatan pembangunan daerah di berbagai sektor dan mengatur rumah tangganya sendiri. Sejalan dengan upaya meningkatkan kemandirian dan mengurangi ketergantungan daerah kepada pusat dalam membiayai pembangunan daerah, diharapkan kabupaten Morowali berusaha secara aktif dalam meningkatkan sumber-sumber penerimaan terutama peneriman yang berasal dari Pendapatan Asli Daerah (PAD). realisasi pendapatan dari tahun 2012 sampai 2013, ini rata-rata mengalami peningkatan dari $16,50 \%$ tahun $2012,19,17 \%$ tahun 2013. Adanya peningkatan tersebut adalah merupakan upaya pemerintah daerah untuk melakukan evaluasi terhadap objek-objek pendapatan yang ada di Kabupaten Morowali. Namun pada tahun 2014 mengalami 
penurunan menjadi $10,15 \%$, hal ini disebabkan terbentuknya daerah otonomi baru Kabupaten Morowali Utara, yang mengakibatkan terjadinya pemisahan atau pembagian objek pendapatan yaitu antara Kabupaten Morowali Utara dan Kabupaten Morowali. Selain itu, pada tahun 2012-2014 Kabupaten Morowali tidak mendapatkan dana hibah serta adanya pelarangan ekspor bahan mineral mentah di tahun 2014. Pada tahun 2015 dan 2016 ini kembali mengalami peningkatan dari 10,15\% menjadi $17,90 \%$ dan $19,80 \%$, hal ini sangat dipengaruhi oleh beroperasinya kembali beberapa perusahaan tambang yang ada di Kabupaten Morowali yang secara keseluruhan mampu meningkatkan kembali realisasi pendapatan daerah khususnya pada lain-lain pendapatan yang sah. Hal ini di ikuti pula dengan realisasi belanja yang berimbang dengan realisasi pendapatan, adapun penurunan realisasi belanja di tahun 2014, hal ini juga tidak terlepas dari pengaruh terbentuknya daerah Otonomi Baru Kabupaten Morowali Utara yang terbentuk di tahun 2014, sehingga wilayah menjadi terbagi yang kemudian dari sisi pelaksanaan program kegiatan pun menjadi terbagi dua antara Kabupaten Morowali dan Kabupaten Morowali Utara, dan tujuan penelitian ini untuk mendeskripsikan dan menganalisis Kinerja Keuangan dan Kemandirian Daerah Kabupaten Morowali.

\section{KAJIAN LITERATURE DAN PENGEMBANGAN HIPOTESIS Manajemen Keuangan Daerah}

Manajemen merupakan proses perencanaan, pengorganisasian, pengarahan, pengkoordinasian, dan pengawasan usaha-usaha para anggota organisasi dan penggunaan sumber daya organisasi lainnya agar mencapai tujuan yang telah ditetapkan. Dari pengertian tersebut, jelas bahwa manjemen mempunyai empat fungsi dasar, yaitu perencanaan, pengorganisasian, kepemimpinan, dan pengendalian. Konsep dasar dari manajemen tersebut dapat diaplikasikan dalam berbagai jenis organisasi, termasuk lingkungan organisasi sector publik tidak terkecuali dalam pengelolaan keuangan daerah. (Yuwono dalam Rudiyanto, 2015).

\section{Anggaran Pendapatan dan Belanja Daerah}

Menurut Mahsun (2015:81) Anggaran Pendapatan, dan Belanja Daerah (APBD) adalah daftar yang memuat rincian penerimaan daerah dan pengeluaran/belanja daerah selama satu tahun yang ditetapkan dengan peraturan daerah (Perda) untuk masa satu tahun, mulai dari tanggal 1 Januari sampai dengan tanggal 31 Desember.

APBD terdiri atas anggaran pendapatan,anggaran belanja, dan pembiayaan. Pendapatan daerah berasal dari pendapatan asli daerah, dana perimbangan, dan lain-lain pendaptan yang sah. Pendapatan daerah merupakan hak pemerintah daerah yang diakui sebagai penambah nilai kekayaan bersih. Belanja daerah dirinci menurut organisasi fungsi, dan jenis belanja. Belanja daerah merupakan kewajiban pemerintah daerah yang diakui sebagai pengurung nilai kekayaan bersih.

\section{Kinerja Keuangan Daerah}

Kinerja keuangan Pemerintah Daerah adalah kemampuan suatu daerah untuk menggali dan mengelola sumber-sumber keuangan asli daerah dalam memenuhi kebutuhannya guna mendukung berjalannya sistem pemerintahan, pelayanan kepada masyarakat dan pembangunan daerahnya dengan tidak tergantung sepenuhnya kepada pemerintah pusat dan mempunyai keleluasaan di dalam menggunakan dana-dana untuk kepentingan masyarakat daerah dalam batas-batas yang ditentukan peraturan perundang-undangan (Rudiyanto,2015). Sistem pengukuran kinerja sendiri dapat dijadikan sebagai alat pengendalian organisasi. Pemerintah Daerah mempunyai kinerja yang baik apabila Pemerintah Daerah mampu untuk melaksanakan tugas-tugas dalam rangka mencapai tujuan yang telah ditetapkan pada standar yang tinggi dengan biaya yang rendah. Kinerja yang baik bagi Pemerintah Daerah dicapai ketika administrasi dan penyediaan jasa oleh Pemerintah Daerah dilakukan pada tingkat yang ekonomis, efektif dan efisien. 


\section{Kemandirian Daerah}

Kemandirian keuangan daerah (otonomi fiskal) mengindikasikan kemampuan Pemerintah Daerah dalam membiayai sendiri kegiatan pemerintahan, pembangunan, dan pelayanan masyarakat yang telah membayar pajak dan retribusi sebagai sumber pendapatan daerah (Abdul Halim,2012). Selanjutnya Abdul Halim (2012) menyatakan bahwa kemandirian keuangan daerah ditunjukkan oleh besar kecilnya pendapatan asli daerah (PAD) dibandingkan dengan pendapatan daerah yang berasal dari sumber lainnya misalnya bantuan pemerintah pusat (transfer pusat) maupun dari pinjaman. Kemandirian daerah ditunjukkan oleh besar kecilnya Rasio kemandirian juga yang mengarah pada ketergantungan daerah terhadap sumber dana eksternal, terutama dari pemerintah pusat dan provinsi. Semakin tinggi rasio kemandirian daerah, tingkat ketergantungan terhadap bantuan pihak eksternal (terutama pemerintah pusat dan provinsi) semakin rendah, dan sebaliknya semakin rendah rasio kemandirian maka semakin tinggi tinkat ketergantungan terhadap pemerintah pusat.

\section{METODE PENELITIAN}

Jenis Penelitian yang dipakai dalam penelitian ini adalah penelitian deskriptif dengan pendekatan kuntitatif. penelitian ini merupakan penelitian deskriptif kuantitatif yaitu melakukan perhitunganperhitungan terhadap data keuangan yang diperoleh untuk memecahkan masalah yang ada sesuai dengan tujuan penelitian,

Penelitian ini berupaya untuk mendeskripsi-kan, menganalis dan menginterpretasikan kinerja keuangan dan kemandirian keuangan pemerintah daerah Kabupaten Morowali yang diukur melalui perhitungan rasio keuangan berdasarkan laporan realisasi APBD tahun anggaran 2012-2016 dan disajikan dalam bentuk tulisan secara sistematis.

Fokus dalam penelitian ini adalah kemandirian Kabupaten Morowali tahun anggaran 2012-2016 dan Kinerja Keuangan Pemerintah Daerah Kabupaten Morowali tahun anggaran 2012-2016. Lokasi penelitian di Kabupaten Morowali dan situs penelitian pada Badan Pengelola Keuangan dan Aset Daerah Kabupaten Morowali.

Teknik pengumpulan data dilakukan dengan wawancara dan dokumentasi. Penelitian ini menggunakan data primer berupa hasil wawancara dan data sekunder berupa data Laporan realisasi APBD Kabupaten Morowali tahun 2012-2016.

Penelitian ini digambarkan dalam bentuk Operasional Variabel mengukur variabel kinerja keuangan menggunakan rasio efektifitas, rasio efisisensi, rasio ekonomis dan variabel kemandirian daerah menggunakan rasio kemandirian dengan indikator pendapatan asli daerah dan pendapatan transfer.

Teknis analisis yang di gunakan adalah analisis rasio. Alat analisis yang digunakan dalam penelitian ini adalah sebagai berikut:

a. Rasio Efektivitas

Dengan Rumus:

$$
\text { Rasio Efektivitas PAD }=\frac{\text { Realisasi PAD }}{\text { Anggaran PAD }} \times 100 \%
$$

b. Rasio Efisiensi Keuangan Daerah

Dengan Rumus:

$$
\mathrm{REKD}=\frac{\text { Realisasi Belanja Daerah }}{\text { Realisasi Pendapatan Daerah }} \times 100 \%
$$


Yusuf, S.K.

c. Rasio ekonomis

Dengan rumus:

$$
\text { Rasio Ekonomis }=\frac{\text { Realisasi Pengeluaran }}{\text { Anggaran Pengeluaran }} \times 100 \%
$$

d. Rasio Kemandirian

Dengan Rumus:

$$
\text { Rasio Kemandirian }=\underset{\text { Transfer Pusat }+ \text { Propinsi }+ \text { Pinjaman }}{\text { Pendapatan Asli Daerah }} \times 100 \%
$$

\section{HASIL DAN PEMBAHASAN}

a. Perkembangan APBD Kabupaten Morowali

Hasil perkembangan APBD pemerintah daerah Kabupaten Morowali berdasarkan data realisasi APBD tahun 2012-2016 adalah sebagai berikut:

Tabel 1. APBD Kabupaten Morowali tahun 2012-2016

(dalam ribuan rupiah)

\begin{tabular}{lccccc}
\hline \multicolumn{1}{c}{ URAIAN } & $\mathbf{2 0 1 2}$ & $\mathbf{2 0 1 3}$ & $\mathbf{2 0 1 4}$ & $\mathbf{2 0 1 5}$ & $\mathbf{2 0 1 6}$ \\
\hline Pendapatan & \multicolumn{5}{c}{} \\
\hline PAD & 45.800 .100 & 48.578 .791 & 39.528 .894 & 81.010 .135 & 131.205 .071 \\
\hline P. Transfer & 686.147 .820 & 764.981 .505 & 432.472 .418 & 655.176 .964 & 871.040 .783 \\
\hline \multicolumn{1}{c}{ URAIAN } & $\mathbf{2 0 1 2}$ & $\mathbf{2 0 1 3}$ & $\mathbf{2 0 1 4}$ & $\mathbf{2 0 1 5}$ & $\mathbf{2 0 1 6}$ \\
\hline $\begin{array}{l}\text { Lain-lain } \\
\text { Pendapatan yang sah }\end{array}$ & 59.426 .968 & 76.077 .646 & 48.531 .883 & 210.859 .840 & 170.688 .642 \\
\hline T. Pendapatan & $\mathbf{7 9 1 . 3 7 4 . 8 8 9}$ & $\mathbf{8 8 9 . 6 3 7 . 9 4 3}$ & $\mathbf{5 2 0 . 5 3 3 . 1 9 5}$ & $\mathbf{9 4 7 . 0 4 6 . 9 3 9}$ & $\mathbf{1 . 1 7 2 . 9 3 4 . 4 9 7}$ \\
\hline Belanja & & & & & \\
\hline B. langsung & 427.086 .879 & 462.805 .725 & 282.978 .404 & 369.255 .654 & 640.608 .925 \\
\hline B. tidak langsung & 386.415 .133 & 437.872 .527 & 299.632 .066 & 469.399 .749 & 490.201 .369 \\
\hline T. Belanja & $\mathbf{8 1 3 . 5 0 2 . 0 1 2}$ & $\mathbf{9 0 0 . 6 7 8 . 2 5 3}$ & $\mathbf{5 8 2 . 6 0 2 . 4 7 1}$ & $\mathbf{8 6 5 . 6 5 5 . 4 0 4}$ & $\mathbf{1 . 1 3 0 . 8 1 0 . 2 9 4}$ \\
\hline Surplus/Defisit & $\mathbf{( 2 2 . 1 2 7 . 1 2 3 )}$ & $\mathbf{( 1 1 . 0 4 0 . 3 1 0 )}$ & $\mathbf{( ( 6 2 . 0 6 8 . 2 7 5 )}$ & $\mathbf{8 1 . 3 9 1 . 5 3 5}$ & $\mathbf{4 2 . 1 2 4 . 2 0 3}$ \\
\hline Sumber: BPKAD $K a b u$ & & & &
\end{tabular}

Sumber: BPKAD Kabupaten Morowali

Berdasarkan Tabel 1 dapat dilihat anggaran pendapatan Kabupaten Morowali tahun 2012-2013 mengalami peningkatan tiap tahunnya, tetapi pada tahun 2014 mengalami penurunan sebesar 12,50\%, menurunnya Anggaran pendapatan tidak merupakan dampak diterpkannya Peraturan Pemerintah No 1 tahun 2014 Tentang Pelarangan Ekspor Bahan Mineral Mentah yang dibarengi dengan pemekaran wilayah kabupaten Morowali, sehingga terjadi beberapa pemisahan objek pendapatan yang berpengaruh pada anggaran pendapatan dan belanja daerah. Kemudian pada tahun 2015 dan tahun 2016 anggaran pendapatan Kabupaten Morowali kembali mengalami peningkatan sebesar 21,91\% dan $27,14 \%$, hal ini disebabkan telah dilaksanakan peresmian pengoperasian smelter pada perusahaan tambang serta adanya upaya pemerintah dalam meningkatkan objek-objek pendapatan yang ada di Kabupaten Morowali. Hal ini diikuti pula dengan belanja daerah yang mengalami fluktuasi. Secara keseluruhan belanja langsung menyerap dana terbesar dengan komponen belanja lainnya. Besarnya penyerapan dana belanja langsung disebabkan karena besarnya dana yang digunakan pemerintah daerah untuk belanja pegawai. Belanja langsung terbesar terjadi pada tahun 2016 disebabkan karena meningkatnya belanja modal, hal ini merupakan upaya pemerintah daerah dalam meningkatkan asset dan meningkatkan infrastruktur guna meningkatkan pendapatan daerah. 


\section{b. Rasio Efektifitas kabupaten Morowali 2012-2016}

Hasil perhitungan rasio efektivitas Kabupaten Morowali ditunjukkan oleh tabel berikut ini:

\section{Tabel 2. Hasil Perhitungan Rasio Efektivitas PAD}

Kabupaten Morowali tahun Anggaran 2012-2016

(Dalam Ribuan Rupiah)

\begin{tabular}{ccccc}
\hline Tahun & Realisasi PAD & Anggaran PAD & $\begin{array}{c}\text { Rasio } \\
\text { Efektifitas } \\
\text { PAD }\end{array}$ & Kriteria \\
\hline 2012 & 30.528 .399 & 45.800 .100 & $66,66 \%$ & Tidak Efektif \\
\hline 2013 & 39.134 .372 & 48.578 .791 & $80,56 \%$ & Kurang Efektif \\
\hline 2014 & 25.341 .127 & 474.143 .569 & $64,10 \%$ & Tidak Efektif \\
\hline 2015 & 74.439 .927 & 81.010 .135 & $91,88 \%$ & Cukup Efektif \\
\hline 2016 & 47.434 .380 & 131.205 .071 & $36,71 \%$ & Tidak Efektif \\
\hline & Rata-rata & & $\mathbf{6 7 , 8 7 \%}$ & Tidak Efektif \\
\hline
\end{tabular}

Sumber: BPKAD Kabupaten Morowali

Berdasarkan perhitungan dalam Tabel 2. dapat diketahui bahwa rasio efektivitas PAD Kabupaten Morowali, masih tergolong tidak efektif karena memilki rata-rata $<75 \%$ yaitu sebesar $67,87 \%$. Berdasarkan pedoman Mahmudi (2016:14) menunjukan pada tahun 2015 rasio efektifitas menujukan cukup efektif dengan nilai 91,88\%, menujukan pemerintah daerah sudah cukup mampu dalam mengenali dan mengelola PAD. Hal ini terjadi tidak lain dengan mulai beroperasinya smelter untuk mengelola mineral mentah yang mempengaruhi total penerimaan pendapatan asli daerah.

Lain halnya pada tahun 2016, pada tahun ini tingkat efektivitas pendapatan asli daerah menunjukan nilai yang tidak efektif yaitu sebesar $36,71 \%$ karena masih kurang $<75 \%$, hal ini disebkan pada tahun 2016 adanya peninjauan kembali tentang sistim penarikan pajak daerah dikarenakan adanya beberapa wajib pajak yang tidak taat pada aturan yang telah di tetapkan, begitu pula yang terjadi pada tahun 2012 dan 2014. Sedangkan pada tahun 2013 cenderung membaik dari tahun sebelumnya yaitu termasuk dalm kategori kurang efektif karena berada pada interval 75\%-89\% dengan nilai $80,56 \%$. Hal ini terjadi karena adanya peningkatan jumlah restoran dan peningkatan tenaga listrik untuk penerangan jalan serta meningkatnya retribusi daerah yang diterima. Pernyataan ini berdasarkan wawancara yang dilakukan pada kantor BPKAD Kabupaten Morowali.

\section{c. Rasio Efesiensi kabupaten Morowali 2012-2016}

Hasil perhitungan rasio Efesiensi Kabupaten Morowali ditunjukkan oleh tabel berikut ini:

Tabel 3. Hasil perhitungan Rasio Efisiensi Keuangan Daerah

Kabupaten Morowali tahun Anggaran 2012-2016

(Dalam Ribuan Rupiah)

\begin{tabular}{ccccc}
\hline Tahun & $\begin{array}{c}\text { Realisasi } \\
\text { Belanja }\end{array}$ & $\begin{array}{c}\text { Realisasi } \\
\text { Pendapatan }\end{array}$ & REKD & Kriteria \\
\hline 2012 & 744.587 .716 & 769.737 .506 & $96,73 \%$ & Kurang Efisien \\
\hline 2013 & 858.042 .386 & 894.453 .135 & 95,735 & Kurang Efisien \\
\hline 2014 & 474.143 .569 & 473.467 .933 & $100,14 \%$ & Tidak Efisien \\
\hline 2015 & 779.495 .582 & 835.127 .978 & $93,33 \%$ & Kurang Efisien \\
\hline 2016 & 855.900 .973 & 923.703 .292 & $95,66 \%$ & Kurang Efisien \\
\hline \multicolumn{5}{c}{ Rata-rata } \\
\hline
\end{tabular}

Sumber: BPKAD Kabupaten Morowali 
Yusuf, S.K.

Berdasarkan perhitungan dalam Tabel 3. terlihat bahwa efisiensi keuangan daerah Kabupaten Morowali berfluktuasi dari tahun ke tahun. Berdasarkan penilaian menurut Halim (2007:234) menunjukan bahwa pada tahun 2012 sampai tahun 2016 semua angka pada rasio efisien memiliki angka di atas $65 \%$ dengan rata-rata rasio efisiensi sebesar $96,33 \%$ dan tergolong tidak efisien. Hal ini ditunjukan terjadinya selisih yang cukup besar antara realisasi pendapatan dengan realisasi belanja daerah.

Tinggkat efisiensi keuangan daerah dari tahun ke tahun cenderung berfluktuasi. Rasio efisiensi tertinggi terjadi pada tahun 2014 dengan nilai rasio sebesar 100,14\%, hal ini terjadi akibat besarnya realisasi belanja daerah dibandingkan dengan realisasi pendapatan daerah yang disebabkan oleh pemekaran wilayah Kabupaten Morowali Utara walaupun pada tahun 2014 pemerintah daerah telah menekan belanja daerah terutama pada belanja pegawai. Pernyataan ini berdasarkan wawancara pada kantor BPKAD Kabupaten Morowali.

\section{d. Rasio Ekonomis kabupaten Morowali 2012-2016}

Hasil perhitungan rasio Ekonomis Kabupaten Morowali ditunjukkan oleh tabel berikut ini:

Tabel 4. Hasil perhitungan Rasio Ekonomis Keuangan

Kabupaten Morowali Tahun Anggaran 2012-2016

(Dalam Ribuan Rupiah)

\begin{tabular}{ccccl}
\hline Tahun & $\begin{array}{c}\text { Realisasi } \\
\text { Belanja }\end{array}$ & $\begin{array}{c}\text { Anggaran } \\
\text { Belanja }\end{array}$ & $\begin{array}{c}\text { Rasio } \\
\text { Ekonomis }\end{array}$ & Kriteria \\
\hline 2012 & 744.587 .716 & 813.502 .012 & $91,33 \%$ & Ekonomis \\
\hline 2013 & 858.042 .386 & 900.678 .253 & $95,27 \%$ & Ekonomis \\
\hline 2014 & 474.143 .569 & 582.601 .471 & $81,38 \%$ & Ekonomis \\
\hline 2015 & 779.495 .582 & 865.655 .404 & $90,03 \%$ & Ekonomis \\
\hline 2016 & 855.900 .973 & 1.130 .810 .294 & $75,69 \%$ & Ekonomis \\
\hline \multicolumn{7}{c}{ Rata-rata } & & $\mathbf{8 6 , 7 8 \%}$ & Ekonomis \\
\hline
\end{tabular}

Sumber: BPKAD Kabupaten Morowali

Berdasarkan perhitungan dalam Tabel 4. dapat dilihat perkembangan rasio ekonomis Kabupaten Morowali dari tahun 2012 sampai tahun 2016 cenderung berfluktuasi dari segi nominalnya. Berdasarkan penilaian mardiasmo dalam Feriskasari (2014:12) menunjukan rasio ekonomis Kabupaten Morowali pada 5 tahun terkakhir cukup konsisten pada kategori ekonomis. walaupun terjadi fluktuasi presentase pada tahun 2012 ke tahun 2013 mengalami penurunan 4,08\% dari 91,53\% menjadi 92,27\%. Hal ini disebabkan setiap tahunnya Kabupaten Morowali dalam menetapkan anggran melakukan disiplin anggaran seperti pada belanja rutin yang meliputi belanja pegawai, belanja hibah, belanja bunga, dan belanja bantuan sosial. Pernyataan ini berdasarkan wawancara yang dilakuakan pada kantor BPKAD Kabupaten Morowali.

\section{e. Rasio Kemandirian}

Hasil perhitungan rasio Kemandirian Kabupaten Morowali ditunjukkan oleh tabel berikut ini:

Tabel 5. Hasil perhitungan Rasio Kemandirian Keuangan

Kabupaten Morowali Tahun Anggaran 2012-2016

(Dalam Ribuan Rupiah)

\begin{tabular}{cccccc}
\hline Tahun & PAD & $\begin{array}{c}\text { Pendapatan } \\
\text { Transfer }\end{array}$ & RRKD & Kriteria & $\begin{array}{c}\text { Pola } \\
\text { Hubungan }\end{array}$ \\
\hline 2012 & 30.528 .399 & 679.665 .236 & $4,49 \%$ & Sangat Rendah & Instruktif \\
\hline 2013 & 39.134 .372 & 782.589 .490 & $5,00 \%$ & Sangat Rendah & Instruktif \\
\hline
\end{tabular}




\begin{tabular}{|c|c|c|c|c|c|}
\hline 2014 & 25.341 .127 & 402.072 .482 & $6,30 \%$ & Sangat Rendah & Instruktif \\
\hline 2015 & 74.439 .927 & 659.252 .373 & $11,28 \%$ & Sangat Rendah & Instruktif \\
\hline 2016 & 47.434 .380 & 729.390 .922 & $6,50 \%$ & Sangat Rendah & Instruktif \\
\hline & Rata-rata & & $6,75 \%$ & & Instrukti \\
\hline
\end{tabular}

Sumber: BPKAD Kabupaten Morowali

Berdasarkan perhitungan dalam Tabel 5. dapat dilihat bahwa rata-rata rasio kemandirian Kabupaten Morowali tahun 2012-2016 masih tergolong sangat rendah dengan rata-rata rasio sebesar 6,75\%. Berdasarkan standar penilaian halim dalam Gramini (2017: 34), hasil ini menunjukan bahwa dalam pelaksanaan otonomi daerah Kabupaten Morowali memiliki tingkat kemandirian yang rendah sekali dengan pola hubungan instruktif.

Rendahnya tasio kemandirian disebabkan karena PAD Kabupaten Morowali masih sagat rendah jika dibandingkan dengan pendapatan transfer. Tingginya pendaptan transfer pada bagian DAU yang diterima daerah yang dipengaruhu oleh jumlah penduduk, luas wilayah, PDRB per Kapita dan indeks pembangunan manusia. Tingkat kemandirian tertinggi terjadi pada tahun 2015 yaitu 11,28\% karena pada tahun 2015 telah dilaksanakan pengoperasian smelter untuk pengolahan bahan mineral mentah dan Kabupaten Morowali menerima dana BLUD sehingga mampu mengimbangi peningkatan pendapatan transfer. Sedangkan tingkat kemandirian terendah terjadi pada tahun 2012 yaitu 4,49\% yang disebabkan tidak efektifnya pemerintah daerah dalam mengelola potensi daerah sehingga PAD tidak mampu mengimbangi peningkatan pendapatan transfer. Pernyataan ini berdasarkan wawancara pada kantor BPKAD Kabupaten Morowali.

\section{KESIMPULAN DAN SARAN}

\section{a. Kesimpulan}

Berdasarkan hasil penelitian dan pembahasan terhadap analisis kinerja keuangan dan kemandirian daerah Kabupaten Morowali, maka dapat ditarik kesimpulan sebagai berikut:

1. Berdasarkan hasil analisis rasio efektifitas PAD Kabupaten Morowali tahun 2012-2015 termasuk dalam kategori tidak efektif karena rata-rata rasionya berada dibawah $100 \%$ sebesar 67,87\%, yang mengindikasikan bahwa Kabupaten Morowali belum efektif dalam memobilisasi penerimaan Pendapatan Asli Daerah.

2. Berdasarkan hasil analisis rasio efisiensi keuangan daerah Kabupaten Morowali tahun 2012-2016 termasuk dalam kategori tidak efisien karena rata-rata rasionya berada diatas 65\% sebasar 96,47\%, yang mengindikasikan Kabupaten Morowali belum efisien dalam Menggunakan anggaran belanja daerah untuk mendapatkan pendapatan daerah.

3. Berdasarkan rasio ekonomis Kabupaten Morowali tahun 2012-2016 termasuk dalam kategori ekonomiskarena rata-rata rasionya berada dibawah $100 \%$ sebesar $86,78 \%$, yang berarti Kabupaten Morowali sudah ekonomis dalam menggunakan anggaran belanja dalam melaksanakan suatu pelayanan di daerah.

4. Tingkat kemandirian Kabupaten Morowali tahun 2012-2016 masih tergolong sangat rendah adalah $6,75 \%$ dengan pola hubungan instruktif, yang berarti peran pemerintah pusat dalam pelaksanaan desentralisasi masih sangat tinggi.

\section{b. Saran}

Berdasarkan kesimpulan dari hasil penelitian, maka dapat diajukan beberapa saran sebagai berikut:

1. Pemerintah Daerah harus mampu mengoptimalkan penerimaan dari potensi pendapatannya yang telah ada. Inisiatif dan kemauan Pemerintah Daerah sangat diperlukan dalam upaya peningkatan PAD. Peningkatan PAD bisa dilakukan Pemerintah 
Yusuf, S.K.

Daerah dengan cara melaksanakan secara optimal pemungutan pajak dan retribusi daerah serta melakukan pengawasan dan pengendalian secara sistematis dan berkelanjutan untuk menghindari penyalahgunaan pendapatan asli daerah.

2. Tingkat kemandirian yang sangat rendah dengan pola instruktif menjadi salah satu masalah dalam pemerintahan Kabupaten Morowali, untuk itu pemerintah daerah perlu mengenali dan menggali potensi yang ada dalam daerah serta peningkatan sumber daya manusia sangat di butuhkan dalam partisipasi pembangunan daerah.

\section{REFERENSI}

Badan Pengelola Keuangan Daerah, 2016. Realisasi Anggaran Pendapatan dan Belanja Daerah Periode 2012-2016. Badan Pengelola Keuangan Daerah Kabupaten Morowali, Sulawesi Tengah.

Feriskasari, C Nindy. (2014). Analisis Pengukuran Kinerja Pemerintah Daerah Dengan Menggunakan Prinsip Value For Money (Studi Kasus Kabupaten Sumenep Tahun 2010-2013), Skripsi, Universitas Negeri Surabaya

Gramini, Media. (2017). Analisis Kinerja Anggaran Pendapatan dan Belanja Daerah (APBD) Kabupaten Morowali Pada Pariode Tahun 2011-2015,Skripsi, Universitas Tadulako Palu.

Halim, Abdudan Iqbal. (2012). Pengelola Keuangan Daerah. Edisi Ketiga. Yogyakarta: UPP AMP YKPN.

Halim, Abdul. 2007. Akuntansi SektorPublik: Akutansi Keuangan Daerah. Edisi Ketiga. Jakarta: Salemba Empat.

Mahmudi. (2016). Analisis Laporan Keuangan Pemerintah Daerah Edisi Ketiga. Yogyakarta: UPP STIM YKPN.

Mahsun, Mohammad, (2015). Akutansi Sektor Publik. Yogyakarta: BPFE.

Rudiyanto, Muhamad, (2015). Analisis Kinerja Keuangan Serta Kemampuan Keuangan Pemerintah Daearah dalam Pelaksanaan Otonomi Daerah: Studi Pada Daerah Kabupaten/Kota di Provinsi Daerah Istimewa Yogyakarta dan Provinsi Banten, Skripsi, Universitas Diponegoro Semarang. 